\title{
Audiovisual Translation Research in Brazil and in Europe
}

\section{Lina Alvarenga}

Universidade de São Paulo

\author{
Vera Lúcia Santiago Araújo \\ Universidade Estadual do Ceará \\ Eliana Paes Cardoso Franco \\ Universidade Federal da Bahia
}

\begin{abstract}
Este artigo apresenta contribuições de três pesquisadoras de tradução que discutem a situação atual das pesquisas sobre tradução audiovisual no Brasil e na Europa. A primeira contribuição trata de questões correlatas aos dois contextos enquanto que as duas outras enfocam questões de pesquisa de interesse local.

This article presents contributions from three translation scholars aimed at discussing the present situation of audiovisual translation research in Brazil and in Europe. The first contribution deals with issues concerning both contexts whereas the two others focus on local research issues.
\end{abstract}

\section{The subject perspective (by Eliana P. C. Franco)}

Audiovisual translation is a recent field of research if compared to other fields, such as literary translation and technical translation. Despite that, audiovisual (interlingual) translation has already been the focus of a respectable number of publications - by scholars and practitioners. However, these publications make clear that research developments are still limited in terms of the modes of transfer and of the genres studied.

Two facts are unquestionable when it comes to audiovisual interlingual translation research, both here in Brazil and in Europe: 
(a) The focus on subtitling and dubbing. Television interpreting and voice-over translation have constantly been ignored by researchers. Quoting Jean-Pierre Mailhac, who wrote about the voice-over of commercial videos: "Audio-visual translation appears to be essentially synonymous with subtitling and dubbing" (in Gambier (ed.) 1998:208).

(b) The focus on fictional output, mostly on feature films, in spite of the fact that factual output represents a large portion within the media repertoire. Moreover, although factual output is frequently subtitled, subtitling is often studied within fiction. This preference for fiction may also be observed in statistics on television broadcasting - such as those published by the European Research Institute or by the European Audiovisual Observatory - where figures concerning factual programs ar0e rarely given much attention, if any.

A good illustration of these two facts is found in the second edition of the Language Transfer and Audiovisual Communication. A Bibliography (1997) compiled by Yves Gambier. It is not a comprehensive bibliography on audiovisual translation, but it is so far the only research reference in the field, where significant data can be found. Among the 1.241 entries that constitute the volume:

(a) Only 21 entries could be identified as studies of television programs which are traditionally accepted as belonging to the non-fictional genre, among them: the documentary film (six entries); current affairs (only one entry); news (nine entries); panel discussions and/or political debates (four entries), and commercials (only one entry).

(b) Entries that mention discourse types most commonly used in factual programs reduced to seven entries for 'commentary'; two entries for 'narration'; and not a single entry for 'interviews'.

(c) Entries about 'voice-over', one of the typical modes of language transfer in factual programs, summed up to 11 .

Thus, the revised volume accounts for the total sum of 41 entries that refer explicitly to non-fiction. However, when entries that do not refer explicitly to the factual genre but might be related to it are considered, then three entries mentioning television programs and 18 entries mentioning interpreting - either for radio or television - could be added to the list, leading to the total of 62 entries.

As I mentioned before, the bibliography is not comprehensive. Brazilian studies, for example, were not included. I recall at least seven dissertations/theses on audiovisual translation, and other research projects that are being developed in the country. But, again, all of them deal with 
subtitling and/or dubbing of fictional output, including my Master dissertation (1991). Current work in Brazil dealing with factual output concerns mainly intralingual translation, such as closed captioning and sign translation. As regards closed captions, Professor Vera Araújo will tell you more about a research that has been conducted at the State University of Ceará (UECE), in Fortaleza.

It is also worth mentioning that a lot has been written since 1997, but I believe that the unbalance between research dealing with fictional output and research dealing with factual output persists, as far as audiovisual interlingual translation is concerned. In my view, there may be at least two reasons for such an unbalanced research situation between fact and fiction. The first reason was already pointed out by Yves Gambier and Eija Sumoela-Salmi (1994), that is, the strong tradition of literature, which has permeated Translation Studies in general and Audiovisual Translation Studies in particular. It has influenced the development of translation theories and models for analysis based on fiction, and it has also affected the choice of focus on fictional audiovisual products and on the modes of language transfer used typically in these products (i.e. subtitling and dubbing).

The second reason, and this is a wild guess, might be a false idea shared by scholars that the translation of facts must not represent a real challenge for any translator; therefore it must be of little interest for the researcher. The translation of facts ends up then being neglected as a boring object of study that lacks the creativity and subjectivity inherent in fiction.

One immediate consequence of the small amount of research concerning factual output is the lack of terminological and conceptual consensus. ${ }^{1}$ This was the first obstacle I had to face in my Doctorate research on voiced-over documentaries, developed at KUL in Belgium. Defining my object of study, voice-over translation, according to the literature available was no easy task. Just to give you an idea, 'voiceover' was defined by an author as 'non-synchronized dubbing', whereas 'synchronized dubbing' was the definition given by another author.

So, I think that more research on audiovisual factual output would lead to a more consistent terminology as far as modes of transfer are concerned, as well as to the acknowledgement of the differences of the uses of these modes among different receptor cultures. For example, I have observed clear differences in the use of voice-over within Europe (e.g. between Western, Central and Eastern Europe; between Denmark, 
Lithuania, Poland and Germany, France, Spain), and between Europe and Brazil. The Brazilian cable television channel People + Arts, for instance, makes use of a voice-over translation model different from the one used in some parts of Europe. In addition to that, the relationship 'program genre and mode of transfer' observed in some European communities does not always hold true in Brazil.

Thus, there is still a lot to be studied in this field. Apart from obstacles, my study on voiced-over documentaries proved to me, in many ways, that factual output is a promising field for audiovisual translation research that should not be underestimated. A research on this kind of output can challenge people's beliefs in relation to the facts presented on small screens as well as theoretical (idealized) statements about their translation. It forces us to think about the ethics involved in the activity; it stimulates interdisciplinarity while stressing the important role of factual audiovisual translation for discussions of media discourse. The research on translated audiovisual facts can finally constitute one important barometer of today's agenda for the globalization of discourse - or the assumption that we exchange information on equal terms.

To conclude, I would like to suggest something that has no connection with what I said previously. I would like to suggest reception research as an asset in audiovisual translation, and I am sure you agree with me. As scholars, we tend to make assumptions about viewers, sometimes underestimating them. We should accept that, as translation scholars, we are more critical viewers. Therefore, we can no longer assume that we share a similar view about audiovisual translation with monolingual viewers. If advance in the field is the goal, we need to know how viewers consume audiovisual translation in reality.

\section{The professional perspective (by Lina Alvarenga)}

In 1991, when Georg-Michael Luyken, director of the European Institute for the Media, published a book called Overcoming Language Barriers in Television, the team Jatalon (or Equipe Jatalon) launched in Brazil the booklet Manual do Vídeo. This booklet was the only national publication for the general audience that explained, among other things, how the Brazilian set of technical parameters for the home video subtitling market was created. While European researchers at EIM discussed the commercial and linguistic aspects of language transfer, Equipe Jatalon's 
professionals defined the basic set of norms and technical standards that have been adopted by all Brazilian subtitling companies to this date.

Equipe Jatalon was the first group of professionals who assessed objectively the quality of electronic subtitles in Brazil. They pointed out, in the section called "Subtitling Techniques", that they did not aim at researching subtitles in their translation aspect. Instead, their idea was:

To put ourselves in the shoes of the viewer who is going to read from seven hundred to two thousand lines of text on screen and who, after this really tough task, should still feel comfortable and be willing to watch another film (1991:78, my translation ${ }^{2}$ )

The question, then, was: How to establish subtitling parameters? Being a highly qualified group of electronic engineers and audiovisual professionals, Equipe Jatalon used to write articles about video equipment and technical essays about audiovisual productions for the newspaper Folha de São Paulo. By 1986, this newspaper had received a lot of letters and phone calls from readers complaining about their difficulty in 'reading' the subtitles of home video films. Due to the lack of subtitle preparation norms, Equipe Jatalon, sponsored by Folha de São Paulo, set out to create them.

The starting point was to answer two questions: (1) What kind of characters are people used to read in Brazil?, and (2) What kind of subtitles are Brazilians used to? Based on newspapers, magazine texts and cinema subtitles, the group decided to establish the following standard rules (Jatalon, 1991:7):

(a) Subtitle texts would be written in upper and lower case.

(b) Font size would comply with the Specifications for Safe Action and Safe Title Areas Test Patterns for Television Systems, established by the Society of Motion Pictures and Television Engineers, in the USA.

(c) One subtitle would have no more than two lines.

(d) One subtitle line would be displayed on screen for at least one second and would be synchronised with the lines spoken by the actors.

(e) Subtitles would be centralised and the words accented according to the official orthographic rules of the Portuguese language.

(f) Subtitles would be yellow in colour.

Having started translating for the home video market ten years ago, only a few years after these rules were created, I feel completely at ease to say that Equipe Jatalon not only established the aesthetics of 
Brazilian subtitles but also defined the boundaries not to be trespassed by subtitling translators from then on. Although it is clear in the booklet that "subtitles are image invading elements, which disturb and steal the viewer's attention from the scenes" (1991:83, my translation $\left.{ }^{3}\right)$, I should point out that Equipe Jatalon was aware of the communicative function of subtitles: their starting point was the viewer's reading comfort.

Those rules have not changed much in the last ten years, and they do not have to change. They are satisfactory. Equipe Jatalon did their job, despite the fact that Brazilian subtitling companies and cable television stations have done very little in order to improve their subtitlers' translation skills. Luckily, most universities in Brazil have noticed the importance of this area and because of that I can share my ten-yearexperience with you today. While, on the one hand, several newspaper and magazine articles have strongly criticised the poor quality of television, home video and cinema translations for nearly 20 years now, on the other hand, we have had an average of one Master dissertation or Doctorate thesis per year in the last decade, which represent very serious studies about this unique form of translation.

Through my working experience at subtitling companies, I have realized that the market out there can only rely on universities to be supplied with trained professionals. That is the best way to improve the quality of our subtitles in all their aspects. Unfortunately, nowadays the Brazilian subtitling industry has different aims, and it will not devote itself to that task.

The idea behind my Master dissertation at USP is to help minimize the impact of subtitles as invading elements in the film, by producing a more "viewer friendly" text in Portuguese.

\section{The academic perspective (by Vera L. S. Araújo)}

Research on audiovisual translation in Brazil is being carried out by both the academy and the companies that deal with this kind of translation, such as subtitling laboratories and dubbing studios. However, in spite of having common interests, there is no exchange of ideas between the academy and these companies. They do their research separately and do not share the results.

In my opinion, this situation must change and it is about time that the dialogue between the people interested in this subject begins. Companies will benefit from academic findings and researchers will have 
access to valuable data and will also get feedback from professionals. Every researcher working in this area knows how difficult it is to collect audiovisual data in our country.

As Lina Alvarenga has already discussed the work conducted by non-academic institutions, my focus here will be mainly on academic research, more specifically the one carried out at the State University of Ceará. But before talking about the Fortaleza experience, let's take a look at what has already been done in the area.

The largest amount of research was produced in the PostGraduation programs of Brazilian universities. Some students interested in audiovisual translation decided to write their theses and dissertations on the subject. They are just isolated projects, not connected to the fields of study developed by the Post-Graduation programs. Most of them, as Eliana Franco pointed out, are about the translation of fiction, focusing on open subtitling. There is no academic research on dubbing and voice over, except for Eliana Franco's thesis (2000), which was written in Europe. Some examples of these studies are the dissertations by Cortiano (1990), Franco (1991), Bamba (1997), Rodrigues (1998), Gonçalves (1998), the thesis by Mouzat (1995) and my own thesis (Araújo, 2000).

At the State University of Ceará, audiovisual translation is one of the fields of study in a research group registered at one of the official government agencies that promote research, CNPq. The group is entitled "Translation and Lexicology" and comprises the works of teachers and of graduate and postgraduate students from Foreign Language Teaching and Applied Linguistics, respectively.

Three of these students are working on screen translation, but from different perspectives. One of them (Carlos Augusto Viana da Silva) is dealing with intersemiotic translation or transmutation, more precisely the translation/adaptation of Virginia Woolf's book Mrs. Dalloway to the screen. The other student (Antônia Célia Nobre) is investigating the importance of knowing audiovisual features when dealing with subtitling. She reflects on a personal experience as an amateur subtitler in Fortaleza. Her task became quite difficult once she approached subtitling as if it were literary translation. It was only during the translation process that she realized that the audiovisual environment should be taken into account. The last student (Graeme Clive Hodgson) is investigating the simultaneous interpreting of the Oscar Awards, especially the translation of humor. 
As to teachers' research at UECE, the main focus nowadays is on closed caption. This form of translation is relatively new in the country and no research on the topic was ever done. Eliana Franco and I are developing a reception research of intralingual subtitles. Our aim is to find out to which extent these subtitles meet Brazilian deaf viewers' expectations and needs.

We borrowed the term "closed caption" from the U.S. because the system available in Brazil to produce these subtitles is the American one. Except for feature films, this system transcribes the speech rather than condenses it. It is different from the European system, which produces intralingual condensed titles, and which is called "closed subtitles" by De Linde \& Kay (1999).

The corpus of our research includes feature films and factual television programs translated by means of closed captioning. They were videotaped from the only Brazilian television channel that exhibits intralingual titles, Rede Globo de Televisão. Closed captions on this channel appear in: (1) all news programs (Bom Dia Brasil, Jornal da Globo, Jornal Nacional, Jornal Hoje); (b) a news magazine (Fantástico); (c) a talk show (O Programa do Jô); (d) some films exhibited on Monday evenings under the series title Tela Quente. Some of the films were: Romeo and Juliet, The Man in the Iron Mask, and The Truth about Cats and Dogs.

The type of tests that will check the effectiveness of the captions has not been set out yet. However, the passages that are going to be used in the tests have already been selected. What is being currently done is the description of the titles exhibited on the Brazilian television channel in the form of a data record that contains all the features that may affect the reception of the titles positively or negatively, such as number of subtitles per minute, shot changes, synchronism between speech, title and image, etc.

I will finish this short exposition by presenting some of the hypotheses we are investigating in this research. So, I will not mention hypotheses related to orality markers that are being investigated mainly by my colleague Eliana Franco. Firstly, we assume that in the news programs, in the television magazine and in the talk show, subtitles do not synchronize with either speech or image. This lack of synchrony may impair the reception of the titles. Secondly, we assume that, in the case of a monologue (e.g. a reporter reading the news), the title can be understood even when it does not synchronize with speech or image. And 
finally, we assume that synchrony that is not observed in factual programs of the corpus is respected in feature films. This helps viewers to make the best of closed captions.

\section{NOTAS:}

1. A whole article about terminological and conceptual issues related to factual audiovisual translation is forthcoming in Target 13:2 (2001), 2002.

2. Representar o usuário que vai ler de 700 a 2000 linhas de legendas e deve, ao final desta verdadeira façanha, sair descansado e capaz de querer assitir outro filme. (Equipe Jatalon, 1991:78)

3. As legendas são como um elemento invasor na imagem, que a mascara, incomoda e tira a atenção da cena para a leitura. (Equipe Jatalon, 1991:93)

\section{REFERÊNCIAS BIBLIOGRÁFICAS}

ARAÚJO, V. L. S. Ser ou não ser natural, eis a questão dos clichês de emoção na tradução audiovisual. São Paulo: Faculdade de Letras da USP, 2000.271p. (Tese, Doutorado em Língua Inglesa e Literaturas Inglesa e Norte-Americana)

BAMBA, M. Da interação da língua falada com a língua escrita a outras formas de interação semiótica na geração de texto de legendas de filmes. São Paulo: Faculdade de Letras da USP, 1997. 216p. (Dissertação, Mestrado em Semiótica e Linguística Geral)

CORTIANO, E. J. A model for assessing the quality of videofilm translation. Curitiba: Faculdade de Letras da UFPR, 1990. 195p. (Dissertação, Mestrado em Língua Inglesa)

DE LINDE, Z., KAY, N. The semiotics of subtitling. Manchester: St. Jerome, 1999. 107p.

EQUIPE JATALON. Manual do Vídeo. São Paulo: Summus, 1991. 119p. FRANCO, E. P. C. Everything you wanted to know about film translation (but did not have the chance to ask). Florianópolis: Faculdade de Letras da UFSC, 1991. 170p. (Dissertação, Mestrado em Língua Inglesa e Literatura Correspondente)

. Revoicing the alien in documentaries. Cultural agency, norms and the translation of audiovisual reality. Leuven: Faculdade de Letras da KUL, 2000. 278p. (Tese, Doutorado em Letras)

GAMBIER, Y., SUOMELA-SALMI, E. Subtitling: A type of transfer. In: Eguíluz, F., MERINO, R., OLSEN, V., PAJARES, E., SANTAMARÍA, J.M. (Eds.) Transvases culturales: Literatura, cine, 
traducción. Vitoria-Gasteiz: Universidad del Pais Vasco, 1994, p.243252.

GAMBIER, Y. (Ed.). Language transfer and audiovisual communication. A bibliography. Turku: Unipaps, 1997. 102p.

. (Ed.). Translating for the media. Turku: Centre for Translation and Interpreting, 1998. 313p.

GONÇALVES, J. L. V. R. Processos inferenciais relacionados à priorização de informações na tradução de legendas de filmes: o redundante e o relevante sob a ótica do princípio da relevância. Belo Horizonte: Faculdade de Letras da UFMG, 1998. 130p. (Dissertação, Mestrado em Estudos Linguísticos)

LUYKEN, G.M. et al. Overcoming language barriers in televisión: dubbing and subtitling for the European audience. Manchester: The European Institute for the Media, 1991. 222p.

MAILHAC, J. P. Optmising the linguistic transfer in the case of commercial videos. In: GAMBIER, Y. (ed.). Translating for the media. Turku: Centre for Translation and Interpreting, 1998. 313p.

MOUZAT, A. M. A forma e o sentido na tradução: a tradução de filmes por legendas. São Paulo: Faculdade de Letras da USP, 1995. 180p. (Tese, Doutorado em Semiótica e Lingüística Geral)

RODRIGUES, R. Por trás das imagens: um estudo da legendação no Brasil. São Paulo: Faculdade de Letras da USP, 1998. 130p. (Dissertação, Mestrado em Língua Inglesa e Literatura Inglesa e Norte-Americana) 